\title{
Tunicates as a biocontrol tool for larvicides acute toxicity of Zika virus vector Aedes aegypti
}

\author{
Velusamy Arumugam ${ }^{1} \cdot$ Manigandan Venkatesan $^{2} \cdot$ Nishakavya Saravanan $^{2} \cdot$ Saravanan Ramachandran $^{2}$. \\ Karthi Sengodan ${ }^{3}$. Umamaheswari Sundaresan ${ }^{1} \cdot$ Satheesh Kumar Palanisamy ${ }^{4}(\mathbb{C}$
}

Received: 9 October 2018 / Accepted: 1 April 2019 / Published online: 9 April 2019

○) King Abdulaziz City for Science and Technology 2019

\begin{abstract}
In this present study, we conducted untargeted metabolic profiling using gas chromatography-mass spectrometry (GC-MS) analysis of ascidian Didemnum bistratum to assess the chemical constituents by searching in NIST library with promising biological properties against anti-bacterial and Zika virus vector mosquitocidal properties. Metabolites, steroids and fatty acids are abundant in crude compounds of ascidian D. bistratum and showed potential zone growth inhibition against bacterial strains Kluyvera ascorbate $(10 \mathrm{~mm})$. The active crude compounds of $D$. bistratum exhibited prominent larvicidal activity against the Zika vector mosquitoes of Aedes aegypti $\left(\mathrm{LC}_{50}\right.$ values of $\left.0.44 \mathrm{mg} / \mathrm{ml}\right)$ and Cluex quinquefasciatus $\left(\mathrm{LC}_{50}\right.$ values of $2.23 \mathrm{mg} / \mathrm{ml}$ ). The findings of this study provide a first evidence of the biological properties exhibited by D. bistratum extracts, thus increasing the knowledge about the Zika virus vector mosquitocidal properties of ascidian. Overall, ascidian D. bistratum is promising and biocontrol or eco-friendly tool against $A$. aegypti and $C$. quinquefasciatus with prospective toxicity against non-target organisms.
\end{abstract}

Keywords Sea squirts · Metabolites · GC-MS · Anti-bacterial $\cdot$ Zika vector $\cdot$ Larvicidal

\section{Introduction}

Since last 50 years, Indian subcontinent has been facing mosquito infectious disease. A. aegypti is the major vector of chikungunya, dengue, and Zika viruses. Zika virus is transmitted to human population mainly through the bite of infected mosquitos. In urban cycle with humans as both reservoir and amplification hosts, and anthropophilic

Satheesh Kumar Palanisamy

indianscientsathish@gmail.com

1 Department of Environmental Biotechnology, School of Environmental Sciences, Bharathidasan University, Tiruchirappalli, Tamil Nadu 620 024, India

2 Native Medicine and Marine Pharmacology Laboratory, Department of Medical Biotechnology, Chettinad Academy of Research and Education, Kelambakkam, Chennai, Tamil Nadu 603 013, India

3 Department of Biochemistry, K.S. Rangasamy College of Arts and Science (Autonomous), Tiruchengode, Namakkal, Tamil Nadu 637 215, India

4 Department of Zoology, Ryan Institute, School of Natural Science, National University of Ireland, Galway, Ireland mosquitoes as vectors (primarily, A. aegypti and secondarily, A. albopictus, C. quinquefasciatus). The implication of $A$. aegypti is the main vector as identified by repeated isolation of ZIKV from field-collected mosquitoes (Diallo et al. 2011), and A. aegypti has been suggested to be involved in transmission as ZIKV has been detected in pools of mosquitos collected in India and Brazil (Boyer et al. 2018). The matured southern house mosquitos $C$. quinquefasciatus are the primary vector of Wuchereria bancrofti, a nematode that causes lymphatic filariasis and also transmits Plasmodium relictum, a malarial parasite of birds. In May 2017, Ministry of Health and Family welfare, Government of India has reported three cases of Zika virus disease in Babunagar, Gujarat, India. The Indian Council of Medical Research screened 34,233 human samples and 12,647 mosquito samples for the presence of Zika virus (WHO 2017). This fact clearly evidences the urgent need for the implementation of innovative and more efficient vector control and discover novel drugs with therapeutic potential.

Tunicates or sea squirts are benthic fouling organisms with great ability to synthesize potential secondary metabolites with potential biomedical applications (Palanisamy et al. 2018a, b). In our previous study, we reported the 
anti-tumor activity of ascidian Phallusia spp. against MCF-7 breast cancer (Palanisamy et al. 2018a, b). Morris et al. (2001) reported that anthrone-anthraquinone compound, albopunctatone isolated from Didemnum albopunctatum collected in Australian Great Barrier Reef, showed a potential activity against malarial parasite Plasmodium falciparum $\left(\mathrm{IC}_{50} 4.4 \mu \mathrm{M}\right)$. In this study, we aimed to chemically characterize Indian Didemnid species Didemnum bistratum and screen their anti-Zika virus vector mosquitocidal activity and anti-bacterial activity using MIC assays.

\section{Materials and methods}

\section{Chemicals}

Methanol (MeOH, HPLC Grade) and sodium sulfate $\left(\mathrm{Na}_{2} \mathrm{SO}_{4}\right.$, Sigma-Aldrich) were used as solvents for extraction of crude extract preparation and successive partition of the aqueous phase and dimethyl sulfoxide (DMSO) for larvicidal activity.

\section{Sample collection and crude compound extraction}

The colonial ascidian D. bistratum (Sluiter, 1905) was collected during the low tide from intertidal reef at Thoothukudi coast (Lat: $8^{\circ} 50^{\prime} 04.9^{\prime \prime} \mathrm{N}$ Long: $78^{\circ} 15^{\prime} 49.7^{\prime \prime} \mathrm{E}$ ), Tamil Nadu, Southeast coast of India. A voucher specimen BDU/EB/ SU/AS/007 has been deposited in the biomaterials lab, Department of Environmental Biotechnology, Bharathidasan University, Tamil Nadu, India. The collected samples were rinsed with sea water, fresh water to remove associated debris and salts. The collected specimen was shade dried and homogenized by mortar and pestle. The coarse powder of D. bistratum (weight $12 \mathrm{~g}$ ) was extracted with methanol $(150 \mathrm{ml})$ using Soxhlet apparatus and the extract was transferred into containers. Furthermore, the salt and $\mathrm{H}_{2} \mathrm{O}$ content in crude compounds was removed using $3 \mathrm{~g}$ of Na $2 \mathrm{SO}_{4}$ and filtered using filter paper size $0.41 \mu \mathrm{m}$. (Suarez-Jimenez et al. 2012).

\section{GC-MS analysis}

The $\mathrm{MeOH}$ extracts of $D$. bistratum was acquired by a newly developed GC-MS method to determine chemical composition using GC with MS Agilent Technologies GC 7890A $240 \mathrm{~ms}$ Ion Trap. The GC injector was set to $260{ }^{\circ} \mathrm{C}$ in split mode condition and the injector temperature was set initially $80{ }^{\circ} \mathrm{C}$ for 1 min with a $4{ }^{\circ} \mathrm{C} / \mathrm{min}$ ramping up to $300{ }^{\circ} \mathrm{C}$ and isotherm for $300{ }^{\circ} \mathrm{C}$ for $5 \mathrm{~min}$. Capillary column CP8877 VF-35 ms with $30 \mathrm{~m} \times 250 \mu \mathrm{m} \times 0.25 \mu \mathrm{m}$ was used. A continuous flow rate of $1 \mathrm{~mL} / \mathrm{min}$ of carrier gas helium was used. The total run time was approximately $49 \mathrm{~min}$. MS detection parameters were set to initial 6 min solvent delay followed by with full scan mode $99-1000(\mathrm{~m} / \mathrm{z})$ with the collection of data from external ionization mode mass range of $10-1000 \mathrm{~m} / \mathrm{z}$ with acquisition data type-centroid, ionization control target TIC 20,000 counts, emission current $25 \mu \mathrm{A}$ and trap temperature was set at $150{ }^{\circ} \mathrm{C}$. The performance value of GC scan rate was at $5600 \mathrm{Da} / \mathrm{s}$. The GC was validated with decaflorobenzophenone/isooctane [4000 MS External NCI, Pref. Eval]. Standard $1 \mathrm{pg} / \mu \mathrm{l}$ which is an external known standard will run regularly and track for the same RT and mass values for every run to be same. The Agilent MS/MS is controlled by an MS Workstation Version 7.0 which GLP and GMP Complied software. The workstation was loaded with the NIST Mass Spectral Search Program for NIST/EPA/NIH Mass Spectral Library Version 2.0.f. The relative metabolites from the sample were determined with the referral of $\mathrm{m} / \mathrm{z}$ table of compounds with mass spectra literature reviews and mass spectral library NIST are given Table 1 (Palanisamy et al. 2018a, b).

\section{Anti-bacterial activity}

The anti-bacterial activities of ascidian $D$. bistratum extract were evaluated using disc diffusion method (Palanisamy et al. 2018a, b). In this study, there are seven bacterial pathogens of Bacillus subtilis: MRSA, Streptococcus sp., Pseudomonas aeruginosa, Kluyvera ascorbata, Escherichia coli, and Klebsiella oxytoca. All the bacterial pathogens were obtained from MTCC, Chandigarh, India. Sterile filter paper disc was used to determine anti-bacterial study of ascidian extracts, $40 \mu \mathrm{l}$ of $\mathrm{MeOH}$ extracts was loaded with sterile discs and antibiotics Ampicillin (10 mg) used as control in this experiment. Following that the plates were swabbed with pathogenic microbes then the discs were placed with nutrient agar (Hi Media, India) plates. The inoculated plates were incubated for $24 \mathrm{~h}$ at $37^{\circ} \mathrm{C}$. After incubation, the zone of inhibition $(\mathrm{mm})$ was measured. The results are presented as mean $\pm \mathrm{SD}$ of the three independent values.

\section{Mosquito culture}

The field population of $A$. aegypti and $C$. quinquefasciatus (WS) larvae were collected from the densely populated area in Salem District, Tamil Nadu, India. Larvae were reared under laboratory conditions and fed with a diet of Brewer's yeast, dog biscuits (Choostix Biskies), and algae collected from ponds in a ratio of 3:2:1, respectively. The WS mosquitoes were reared till reaching the stage adult in the laboratory and were kept isolated to prevent inbreeding until identified to species. Adults were fed with wet raisins and $10 \%$ sucrose solution soaked in cotton. The adult females were deprived of sucrose from $6 \mathrm{~h}$ and then provided with a mouse placed in a breeding cage overnight for 
Table 1 Major compounds identified from crude compounds of colonial ascidian D. bistratum

\begin{tabular}{|c|c|c|c|c|c|}
\hline S. no. & RT & Area, $\%$ & Height, \% & Compound & $\mathrm{m} / \mathrm{z}$ \\
\hline 1. & 17.205 & 1.03 & 1.89 & Pentanoic acid & 105.11 \\
\hline 2. & 18.505 & 0.10 & 0.21 & Dodecanoic acid & 200.31 \\
\hline 3. & 22.110 & 0.38 & 0.50 & Trispiro [4.2.4.2.4.2.] heneicosane & 288.51 \\
\hline 4. & 22.709 & 0.44 & 0.62 & Trimethyldecalin-1-one & 194.31 \\
\hline 5. & 22.957 & 1.46 & 1.19 & Heptadecanoic acid & 270.45 \\
\hline 6. & 24.886 & 0.24 & 0.46 & 1,2-Benzenedicarboxylic acid & 390.55 \\
\hline 7. & 26.504 & 1.79 & 2.02 & Cis-9-octadecene & 252.48 \\
\hline 8. & 27.138 & 7.48 & 3.53 & L-Ascorbyl 2,6-dipalmitate & 652.95 \\
\hline 9. & 27.234 & 0.24 & 0.53 & 5-Eicosene & 280.54 \\
\hline 10. & 27.460 & 0.54 & 0.96 & Eicosanoic acid & 312.53 \\
\hline 11. & 30.279 & 0.45 & 0.50 & Erucic acid & 338.57 \\
\hline 12. & 36.218 & 0.51 & 0.66 & Myristic acid & 228.37 \\
\hline 13. & 41.199 & 0.50 & 0.81 & Cholesta-3,5,24-triene & 366.62 \\
\hline 14. & 41.771 & 0.27 & 0.46 & (22E)-Ergosta-4,7,22-trien-3-ol & 396.64 \\
\hline 15. & 43.360 & 0.22 & 0.54 & Cholest-5-ene,3-methoxy & 368.20 \\
\hline 16. & 43.444 & 0.56 & 1.16 & Stigmastan-3,5,22-trien & 394.20 \\
\hline 17. & 43.513 & 1.34 & 2.33 & Ergosta-5,7-dien-3-ol & 396.659 \\
\hline 18. & 43.600 & 2.79 & 4.78 & Tetrahydrosmilagenin & 420.67 \\
\hline 19. & 44.054 & 58.51 & 46.28 & Epicholestanol & 215.00 \\
\hline 20. & 44.326 & 9.79 & 13.41 & Cholesta-5,22-dien-3 $\beta$-ol & 384.63 \\
\hline 21. & 44.789 & 0.46 & 0.92 & Fucosterol & 314.10 \\
\hline 22. & 44.856 & 4.40 & 5.07 & Allocholesterol & 386.66 \\
\hline 23. & 45.971 & 0.57 & 0.78 & Chondrillasterol & 412.70 \\
\hline 24. & 46.244 & 0.26 & 0.70 & Propionic acid & 74.079 \\
\hline 25. & 47.131 & 0.27 & 0.45 & 3-Ethenylcholestan-3-ol & 414.71 \\
\hline 26. & 47.299 & 0.15 & 0.26 & Cholestan-5-ol-6-one & 402.65 \\
\hline 27. & 47.369 & 0.41 & 0.78 & Hydroquinone & 110.11 \\
\hline 28. & 47.650 & 0.85 & 1.70 & 1,4-Cyclohexadiene & 80.13 \\
\hline 29. & 47.785 & 0.52 & 1.02 & $11 \beta$-18-Epoxylanostane & 428.74 \\
\hline
\end{tabular}

$R T$ retention time

blood feeding. Adult mosquitoes were maintained under the same environmental conditions as the larvae (Arivoli and Samuel 2011).

\section{Larval mortality assay}

Bioassays were performed according to the method recommended by World Health Organization and as suggested by Elumalai et al. (2017). Twenty-five fourth instar larvae were marked in $249 \mathrm{~mL}$ of distilled water with $1 \mathrm{~mL}$ DMSO as negative control. After $24 \mathrm{~h}$ of exposure, dead larvae were calculated and the proportion of dead larvae was calculated from the average of three replicates. Larval mortality was corrected using Abbott's formula. The percentage average mortality of three replicates was used to calculate lethal concentration $\left(\mathrm{LC}_{50}\right.$ and $\left.\mathrm{LC}_{90}\right)$ by prohibit analysis.

\section{Results and discussion}

\section{Metabolites from Didemnid species}

The GC-MS analysis revealed the presence of $>30$ metabolites from the $\mathrm{MeOH}$ extract of D. bistratum (Fig. 1). The GC-MS chromatogram shows the peak area separation of the components and major components epicholestanol (58.51\%), dinorcholesta-5,22-dien-3-ol (9.79\%), 1-(+)ascorbic acid 2,6-dihexadecanoate (7.48\%), allocholesterol $(4.40 \%)$ and other minor compounds of tetrahydrosmilagenin (2.79), 9-octadecene (1.7 9\%), oxirane (1.52\%), ergosta-5,7-dien-3-ol (1.34\%), heptadecanoic acid $(1.46 \%)$, pentanoic acid (1.03\%), 1,4-cyclohexadiene $(0.85 \%), 5$-eicosene $(0.24 \%)$ (Table 1$)$. Similarly, compound of 5-eicosene was previously reported from ascidians Phallusia sp. with potential cytotoxicity against colon 


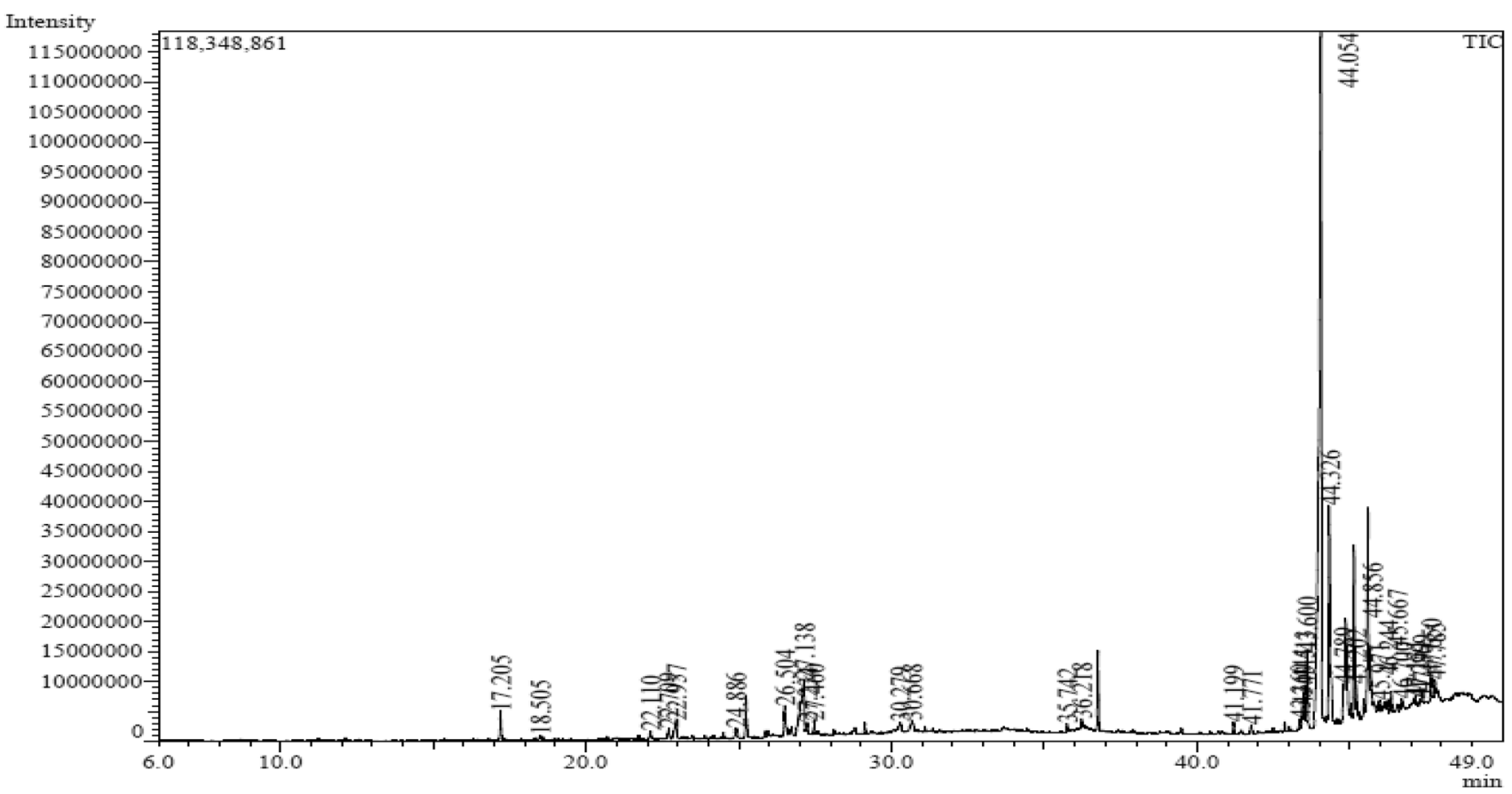

Fig. $1 \mathrm{GC}$ chromatogram for the $\mathrm{MeOH}$ extract of colonial ascidian D. bistratum

cancer cells (Palanisamy et al. 2018a, b) and metabolite, saturated fatty acid eicosanoic acid from Didemnum psammathodes (Kumaran and Bragadeeswaran 2014). Similar to ascidian chemical constituents, sterols are abundance in sponges and marine algae were reported by Santalova et al. (2004), Zhen et al. (2015). Avis and Bélanger (2001) reported that heptadecanoic acid promises the antimicrobial activity against fungal pathogens. The identified compounds from $\mathrm{MeOH}$ extract of $D$. bistratum demonstrate the presence of vital compounds which possess the reported biological activity. This study revealed that the stronger extraction capacity of $\mathrm{MeOH}$ could have produced number of active constituents with unprecedented structures responsible for many biomedical applications.

\section{Anti-bacterial and larvicides acute toxicity of Zika virus vector $A$. aegypti}

The biological activity of $D$. bistratum was screened against anti-Zika vector properties, the results are given in Table 2. We also tested anti-microbial activity against seven bacterial human pathogens (Table 3 ). The MeOH extract of $D$. bistratum exhibited potential zone growth inhibition against human pathogenic strain MSRA $(9.66 \pm 0.57 \mathrm{~mm})$, Klebsiella oxytoca $(9.33 \pm 0.57 \mathrm{~mm})$ and minimum zone was measured with E. coli $(1.33 \pm 0.57 \mathrm{~mm})$ at concentration $25 \mathrm{mg} / \mathrm{ml}$. Hussain and Ananthan (2009) reported that crude methanol extract of $D$. psammathodes showed potential zone growth inhibition against Salmonella typhii $(15 \mathrm{~mm})$ and $D$.
Table 2 Anti-bacterial activity $\mathrm{MeOH}$ extract of $D$. bistratum against the bacterial pathogens

\begin{tabular}{llll}
\hline S. no. & Bacterial pathogens & Control $(\mathrm{mm})$ & $\begin{array}{l}\text { Didemnum } \\
\text { bistratum } \\
(\mathrm{mm})\end{array}$ \\
\hline 1 & Bacillus subtilis & $8.8 \pm 0.03$ & $8.53 \pm 0.03$ \\
2 & MRSA & $9.1 \pm 0.1$ & $9.66 \pm 0.57$ \\
3 & Streptococcus sp. & $8.23 \pm 0.06$ & $4.56 \pm 0.06$ \\
4 & Pseudomonas aeruginosa & $9.43 \pm 0.05$ & $8.66 \pm 0.57$ \\
5 & Kluyvera ascorbata & $10.6 \pm 0.1$ & $9.00 \pm 0.00$ \\
6 & Escherichia coli & $9.93 \pm 0.15$ & $1.33 \pm 0.57$ \\
7 & Klebsiella oxytoca & $8.56 \pm 0.11$ & $9.33 \pm 0.57$ \\
\hline
\end{tabular}

candidum showed poor growth inhibition against Staphylococcus aureas $(1 \mathrm{~mm})$ at $20 \mu \mathrm{l}$ concentration. Compared to the results of our study, Selva Prabhu et al. 2012 reported maximum zone growth inhibition against $E$. coli $(10 \mathrm{~mm})$ of ascidian Polyclinum madrasensis collected from Tuticorin Harbor area. Palanisamy et al. (2016) reported significant anti-microbial activity against Pseudomonas sp compared to control drug $(p<0.01)$ of invasive ascidian Styela plicata from Messina, Italy. He also documented the poor zone growth against the strain Staphylococcus aureus.

The different dose concentrations $(0.02-1.5 \mathrm{mg} / \mathrm{l})$ were chosen to test against second to fourth instar larvae of $A$. aegypti and $C$. quinquefasciatus. The promising mosquito larvicides acute toxicity of Zika virus vector was observed against larval stages of $A$. aegypti with values of LC50 
Table 3 Larvicidal activity of ascidian $D$. bistratum against different instar larvae of dengue vector Ae. aegypti and $C x$. quinquefasciatus

\begin{tabular}{llllll}
\hline Mosquito vector & No. of larvae & LC $_{50}(\mathrm{LCL}-\mathrm{UCL}) \mathrm{mg} / \mathrm{ml}$ & $\mathrm{LC}_{90}(\mathrm{LCL}-\mathrm{UCL}) \mathrm{mg} / \mathrm{ml}$ & $\chi^{2}$ & $d f$ \\
\hline A. aegypti & & & & & \\
IInd instar & 375 & $0.44(0.16-2.18)$ & $21.04(18.67-25.87)$ & 1.56 & 3 \\
IIIrd instar & 375 & $1.34(1.21-2.49)$ & $18.56(15.56-25.87)$ & 3.54 & 3 \\
IVth instar & 375 & $1.98(0.98-2.89)$ & $25.95(22.0-30.91)$ & 4.009 & 3 \\
C. quinquefasciatus & & & & \\
IInd instar & 375 & $2.23(1.94-2.32)$ & $6.73(5.90-8.45)$ & 1.98 & 3 \\
IIIrd instar & 375 & $2.95(2.73-3.09)$ & $8.03(7.90-9.67)$ & 2.23 & 3 \\
IVth instar & 375 & $4.23(3.42-6.83)$ & $9.71(7.73-10.83)$ & 2.53 & 3 \\
\hline
\end{tabular}

$L C_{50}$ lethal concentration $50 \%$ mortality, $L C_{90}$ lethal concentration $90 \%$ mortality, $L C L 95 \%$ lower confidence limits, $U C L$ 95\% upper confidence limits, $\chi^{2}$ Chi-square, $d f$ degrees of freedom and LC90 $0.4436 \mathrm{mg} / \mathrm{ml} ; 21.047 \mathrm{mg} / \mathrm{ml}$ (IInd instar); $1.34167 \mathrm{mg} / \mathrm{ml} ; 18.5678 \mathrm{mg} / \mathrm{ml}$ (IIIrd instar) and $1.9856 \mathrm{mg} /$ $\mathrm{ml} ; 25.9560 \mathrm{mg} / \mathrm{ml}$ (IVth instar) and Cx. quinquefasciatus of LC50 and LC90 values of 2.2371; $6.7321 \mathrm{mg} / \mathrm{ml}$ (IInd instar); $2.9561 ; 8.0317 \mathrm{mg} / \mathrm{ml}$ (IIIrd instar) and 4.239007; $9.71364 \mathrm{mg} / \mathrm{ml}$ (IVth instar), respectively. The previous studies of secondary metabolites from the water and butanol extracts of the ascidians Ascidia sydneinsis, Microcosmus goanus and Phallusia nigra of the Cuban coast have been reported with inhibition (50\%) against the malarial protozoan P. falciparum at concentrations of 20.9, 17.5 and $29.4 \mu \mathrm{g} / \mathrm{ml}$ (Mendiola et al. 2006). Compound, Mollamide B isolated from the ascidian $D$. molle showed promising anti-plasmodiadial activity against the protozoan larva of $P$. falciparum with IC50 of $2.0 \mu \mathrm{g} / \mathrm{ml}$ (Donia et al. 2008). Two indole spermidine alkaloids, Didemnidines A, B reported Didemnum sp collected from Tiwai Point, New Zealand and Didemnidine B has showed modest in vitro growth inhibition against $P$. falciparum and T. brucei rhodesiense IC50 value of 8.4 and $9.9 \mu \mathrm{M}$ (Finlayson et al. 2011). In recent study, Mahyoub et al. (2017) reported that the seagrass Halodule uninervis exhibited significant acute toxicity against fourth instar larvae dengue vector A. aegypti (LC50 $295.62 \mathrm{ppm}$ ). The crude compounds of ascidian Didemnum $\mathrm{sp}$. have strong potential activity against the anti-Zika vector mosquitocidal acute toxicity. The further research on ascidian natural product diversity was conducted to find drug candidates against malarial larvicidal to prevent the infectious disease. The obtained results could serve as a baseline for further research towards designing active anti-bacterial agents against human pathogens and Zika vector mosquito larvicidal to prevent infectious disease.

\section{Conclusions}

The results of this study demonstrated the chemical constituents of least studied Indian ascidian fauna in habituating the area of Gulf of Mannar Biosphere and demonstrated the biological activity of ascidian of Didemnum sp. The extract of $D$. bistratum showed promising anti-Zika vector mosquito larvicidal action than anti-microbial activity. The outcome of this study revealed that ascidian D. bistratum is promising candidate due to the presence of anthroquinone and indole spermidine alkaloids group of compounds responsible for the biocontrol or eco-friendly tool against $A$. aegypti and C. quinquefasciatus with potential toxicity against non-target organisms. The results of this study open new hope for discovering new drug candidate from Indian ascidian with potential therapeutic in the treatment of mosquito-borne diseases and bacterial infections.

Acknowledgements This work is supported by the DST-Science and Research Engineering Board, India under grant SB/YS/LS-374/2013, UGC-FIST and UGC-SAP, New Delhi.

\section{Compliance with ethical standards}

Conflict of interest All the authors declare that they have no conflict of interest.

\section{References}

Arivoli S, Samuel T (2011) Bioefficacy of Citrullus colocynthis (L.) Schrad (cucurbitaceae) whole plant extracts against Anopheles stephensi, Aedes aegypti and Culex quinquefasciatus (Dipters: Culicidae). Int J Curr Res 3:296-304

Avis TJ, Bélanger RR (2001) Specificity and mode of action of the antifungal fatty acid cis-9-heptadecenoic acid produced by Pseudozyma flocculosa. Appl Environ Microbiol 67:956-960

Boyer S, Calvez E, Chouin-Carneiro T, Diallo D, Failloux AB (2018) An overview of mosquito vectors of Zika virus. Microbes Infect 20(11-12):646-660

Diallo D, Sall AA, Diagne CT, Faye O, Faye O, Ba Y, Hanley KA, Buenemann M, Weaver SC, Diallo M (2011) Zika virus emergence in mosquitoes in southeastern Senegal. PLoS One 9(10): 109442

Donia MS, Wang B, Dunbar DC, Desai PV, Patny A, Avery M, Hamann MT (2008) Mollamides B and C, cyclic hexapeptides from the Indonesian tunicate Didemnum molle. J Nat Prod 71(6):941-945

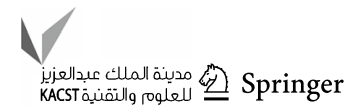


Elumalai D, Hemalatha P, Kaleena PK (2017) Larvicidal activity and GC-MS analysis of Leucas aspera against Aedes aegypti, Anopheles stephensi and Culex quinquefasciatus. J Sau Soc Agric Sci 16:306-313

Finlayson R, Pearce AN, Page MJ, Kaiser M, Bourguet-Kondracki ML, Harper JL, Webb VL, Copp BR (2011) Didemnidines A and $\mathrm{B}$, indole spermidine alkaloids from the New Zealand ascidian Didemnum sp. J Nat Prod 74(4):888-892

Hussain SM, Ananthan G (2009) Antimicrobial activity of the crude extracts of compound ascidians, Didemnum candidum and Didemnum psammathodes (Tunicata: Didemnidae) from Mandapam (South East Coast of India). Curr Res J Biol Sci 1(3):168-171

Kumaran NS, Bragadeeswaran S (2014) Nutritional composition of the Colonial Ascidian Eudistoma viride and Didemnum psammathodes. Biosci Biotech Res Asia 1:331-338

Mahyoub JA, Panneerselvam C, Murugan K, Roni M, Trivedi S, Nicoletti M, Hawas UW, Shaher FM, Bamakhrama MA, Canale A, Benelli G (2017) Seagrasses as sources of mosquito nanolarvicides? Toxicity and uptake of Halodule uninervis-biofabricated silver nanoparticles in dengue and Zika virus vector Aedes aegypti. J Cluster Sci 28(1):565-580

Mendiola J, Hernandez H, Sariego I, Mendiola J, Hernández H, Sariego I, Rojas L, Otero A, Ramírez A, de Los Angeles Chavez M, Payrol JA, Hernández A (2006) Antimalarial activity from three ascidians: an exploration of different marine invertebrate phyla. Trans R Soc Trop Med Hyg 100:909-916

Morris LA, Jaspars M, Kettenes-van den Bosch JJ, Versluis K, Heck AJ, Kelly SM, Price NC (2001) Metal binding of Lissoclinum patella metabolites. Part 1: patellamides A, C and ulithiacyclamide A. Tetrahedron 57(15):3185-3197
Palanisamy SK, Morabito R, Remigante A, Spanò N, La Spada G, Giacobbe S, Marino A (2016) Biological activity of extract from Styela plicata and Ascidia mentula (Ascidiacea). Journal of Biological Research-Bollettino della Società Italiana di Biologia Sperimentale 89(1):27-32

Palanisamy SK, Arumugam V, Peter MD, Sundaresan U (2018a) Patterns of chemical diversity in the marine ascidian Phallusia spp.: anti-tumor activity and metabolic pathway inhibiting steroid biosynthesis. 3 Biotech 8(5):251

Palanisamy SK, Arumugam V, Rajendran S, Ramadoss AS, Nachimuthu S, Peter MD, Sundaresan U (2018b) Chemical diversity and antiproliferative of marine algae. J Nat Prod Res. https://doi. org/10.1080/14786419.2018.148870

Santalova EA, Makarieva TN, Gorshkova IA, Dmitrenok AS, Krasokhin VB, Stonik VA (2004) Sterols from six marine sponges. Biochem Syst Ecol 32(2):153-167

Selva Prabhu A, Ananthan G, Sathish Kumar R (2012) Antibacterial activity of marine ascidian Polyclinum madrasensis (Sebastian, 1952) against human clinical isolates. Int J Ins Phar Life Sci 2(3)

Suarez-Jimenez GM, Burgos-Hernandez A, Ezquerra-Brauer JM (2012) bioactive peptides and depsipeptides with anticancer potential: sources from marine animals. Mar dru 10(5):963-986

WHO (2017) Zika virus infection-India. https://www.who.int/emerg encies/diseases/zika/india-november-2018/en/. Accessed 8 Apr 2019

Zhen XH, Quan YC, Jiang HY, Wen ZS, Qu YL, Guan LP (2015) Fucosterol, a sterol extracted from Sargassum fusiforme, shows antidepressant and anticonvulsant effects. Eur J Pharmacol 768:131-138 